\title{
Coral mortality induced by the 2015-2016 El-Niño in Indonesia: the effect of rapid sea level fall
}

\author{
Eghbert Elvan Ampou ${ }^{1,2,3}$, Ofri Johan ${ }^{4}$, Christophe E. Menkes ${ }^{5}$, Fernando Niño ${ }^{3}$, Florence Birol ${ }^{3}$, Sylvain Ouillon $^{3}$, \\ and Serge Andréfouët ${ }^{1,2}$ \\ ${ }^{1}$ UMR9220 ENTROPIE, Institut de Recherche pour le Développement, Université de la Réunion, CNRS, B.P.A5, 98848, \\ Noumea, New Caledonia \\ ${ }^{2}$ Institute for Marine Research and Observation, SEACORM/INDESO center, Jl. Baru Perancak, Negara-Jembrana, \\ Bali 82251, Indonesia \\ ${ }^{3}$ Laboratoire d'Etudes en Géophysique et Océanographie Spatiales, Université de Toulouse, CNRS, IRD, CNES, UPS, \\ 14 avenue Edouard-Belin, 31400 Toulouse, France \\ ${ }^{4}$ Research and Development Institute for Ornamental Fish Culture, Jl. Perikanan No. 13, Pancoran Mas, Kota Depok, \\ Jawa Barat 16436, Indonesia \\ ${ }^{5}$ Laboratoire d'Océanographie et du Climat: Expérimentations et Approches Numériques, Sorbonne Universités, \\ UPMC Université Paris 06, IPSL, UMR CNRS/IRD/MNHN, B.P.A5-98848, Noumea, New Caledonia
}

Correspondence to: Serge Andréfouët (serge.andrefouet@ird.fr)

Received: 6 September 2016 - Discussion started: 9 September 2016

Revised: 13 January 2017 - Accepted: 3 February 2017 - Published: 24 February 2017

\begin{abstract}
The 2015-2016 El-Niño and related ocean warming has generated significant coral bleaching and mortality worldwide. In Indonesia, the first signs of bleaching were reported in April 2016. However, this El Niño has impacted Indonesian coral reefs since 2015 through a different process than temperature-induced bleaching. In September 2015, altimetry data show that sea level was at its lowest in the past 12 years, affecting corals living in the bathymetric range exposed to unusual emersion. In March 2016, Bunaken Island (North Sulawesi) displayed up to $85 \%$ mortality on reef flats dominated by Porites, Heliopora and Goniastrea corals with differential mortality rates by coral genus. Almost all reef flats showed evidence of mortality, representing $30 \%$ of Bunaken reefs. For reef flat communities which were living at a depth close to the pre-El Niño mean low sea level, the fall induced substantial mortality likely by higher daily aerial exposure, at least during low tide periods. Altimetry data were used to map sea level fall throughout Indonesia, suggesting that similar mortality could be widespread for shallow reef flat communities, which accounts for a vast percent of the total extent of coral reefs in Indonesia. The altimetry historical records also suggest that such an event was not unique in the past two decades, therefore rapid sea level fall could be more
\end{abstract}

important in the dynamics and resilience of Indonesian reef flat communities than previously thought. The clear link between mortality and sea level fall also calls for a refinement of the hierarchy of El Niño impacts and their consequences on coral reefs.

\section{Introduction}

El Niño-Southern Oscillation (ENSO) is the most important coupled ocean-atmosphere phenomenon impacting climate variability at global and inter-annual time scales (McPhaden, 2007). The consequences on coral reefs have been well-documented, especially since the 1997-1998 massive coral bleaching event, which reached planetary dimensions (Hoegh-Guldberg, 1999). In short, El Niño increases temperature in several coral reef regions and induces zooxanthellae expulsion from the coral polyp, resulting in a coral colony looking white, hence "bleaching". If the situation persists the coral colony eventually dies. Coral bleaching intensity has been related to different temperature thresholds, other environmental factors and stressors, and type of zooxanthellae and corals (Baker et al., 2008). Bleach- 
ing episodes due to ocean warming were recorded during the strong 1982-1983 El Niño in Australia (Glynn, 2000) and have since been reported worldwide in several instances (Guest et al., 2012; Wouthuyzen et al., 2015). The last bleaching episode has occurred in 2015-2016 during what occurs to be the strongest El Niño event on record (Schiermeier, 2015). Bleaching events were often global in the past, including Indonesia (Suharsono, 1990; Guest et al., 2012; Wouthuyzen et al., 2015). The last reports for Indonesia in 2016 are still under analysis, and Reef Check survey locations are presented at http://reefcheck.or. $\mathrm{id} / \mathrm{bleaching-indonesia-peringatan/.} \mathrm{Thus,} \mathrm{it} \mathrm{is} \mathrm{assumed} \mathrm{that}$ coral bleaching induced by ocean warming will be the main culprit if post-El Niño surveys report coral mortalities.

While in Bunaken National Park in 23 February-5 March 2016 for a biodiversity survey, we noticed recent mortalities on the upper part of many massive colonies on several reef flats. This prompted a systematic investigation of the phenomenon's spatial distribution. We report here observations on what appears to be the first significant impact of the 20152016 El Niño on Indonesia reefs. Unlike what is expected during such a strong event, the mortality was not related to warm water induced-bleaching, but could be tracked to rapid sea level variations. Coral mortality data around Bunaken Island are provided, and we investigate various altimetry and sea level anomaly data sets to explain mortality. The clear link between mortality and sea level fall calls for a refinement of the hierarchy of El Niño impacts and their sequences on coral reefs.

\section{Material and methods}

Bunaken National Park (BNP) is located at the northwest tip of Sulawesi, Indonesia. The location is at the core of the epicenter of marine biodiversity, the so-called Coral Triangle, a vast area spanning Malaysia to Solomon Island, where the number of marine species is maximum (Hoeksema, 2007). BNP includes several islands with Bunaken Island $\left(1.62379^{\circ} \mathrm{N}, 124.76114^{\circ} \mathrm{E}\right)$, one of the most studied Indonesian reef sites. The Bunaken Island is surrounded by a simple fringing reef system, comprising reef flats, several small enclosed lagoons and forereefs. The tide regime is semidiurnal, but with marked diurnal inequalities (Ray et al., 2005), and with a maximum spring tidal range that can reach $2.52 \mathrm{~m}$. The Bunaken Island is generally exposed to southwest wind from May to October, resulting in calm seas due to the short fetch between mainland and the island, and to northwest wind from November to February, which can be strong at time and generate large waves breaking on the west and north shores.

Two previous BNP surveys for habitat mapping, in MayJune 2014 and May-June 2015, did not show any significant signs of widespread mortalities on reef flats. Different species of corals were frequently exposed above water level at low spring tide, yet they were entirely alive (Fig. 1). Microatolls were present. They have not been studied in Bunaken NP, but as in other sites, their growth is likely constrained by a Mean Low Water (MLW) between Mean Low Water Neaps (MLWN) and Mean Low Water Springs (MLWS) (Smithers and Woodroffre, 2000; Goodwin and Harvey, 2008). Several reef flats were characterized by compact communities of massive and semi-massive colonies that could be described as keep-up communities, limited in their vertical growth by the MLW (in agreement with the terminology of Holocene reefs provided by Neumann and Macintyre, 1985).

In contrast with the 2015 observations, in late February 2016, during a coral biodiversity census survey, we noticed the widespread occurrences of dead massive corals and we performed a systematic investigation on the spatial distribution of the phenomenon. Using the habitat map created by Ampou (2016), all coral habitat polygons present on reef flats around Bunaken Island were visually surveyed and recent mortality was recorded (presence/absence). Geographic coordinates of the presence of mortality were compiled to map its extent. In practice, when mortality was observed on a habitat polygon, the entire polygon was flagged as positive. Then, in different locations around the island, mortality was measured on six reef flat locations characterized by high coral cover and different dominant massive coral species, principally Porites lutea and the octocoral Heliopora coerulea, using six $10 \mathrm{~m}$ long Line Intercept Transect (LIT) (English et al., 1997). We recorded the percent cover of live and dead tissue for each coral and summed the total. We also recorded the species/genus for each coral, and substrate categories between colonies. We did not keep track of the number of colonies present on each transect.

A clear sharp horizontal limit of tissue mortality was present in impacted colonies. The distribution of dead tissue between colonies and among colonies (Fig. 1) suggested that mortality was related to sea level variations, with increased aerial exposure time during the last few months. In order to test this hypothesis, we needed to identify sea level variation data. For this, long-term data from a tidegauge or a pressure sensor are ideal but these were not available for Bunaken. Tide-gauge data are scarce in Indonesia but fortunately there are two tide-gauges in the north of Sulawesi in the city of Bitung, east of Bunaken (latitude $1.430^{\circ} \mathrm{N}$ and longitude $125.200^{\circ} \mathrm{E}$ ) and on the other side of Sulawesi, compared to Bunaken. Thus, while tide-gauge data are available in the region, they are not exactly on Bunaken, but can help visualize the range of conditions found in Bunaken. Bitung data were retrieved from the Sea Level Center in Hawaii (SLCH), specifically at http://uhslc.soest.hawaii.edu/thredds/uhslc_quality_daily. html?dataset=RQD033A. The Sea Surface Height (SSH) provided is referenced, for Bitung, against a GPS station located at Bako (http://www.igs.org/igsnetwork/network_by_ site.php?site=bako) which is itself referenced against the 

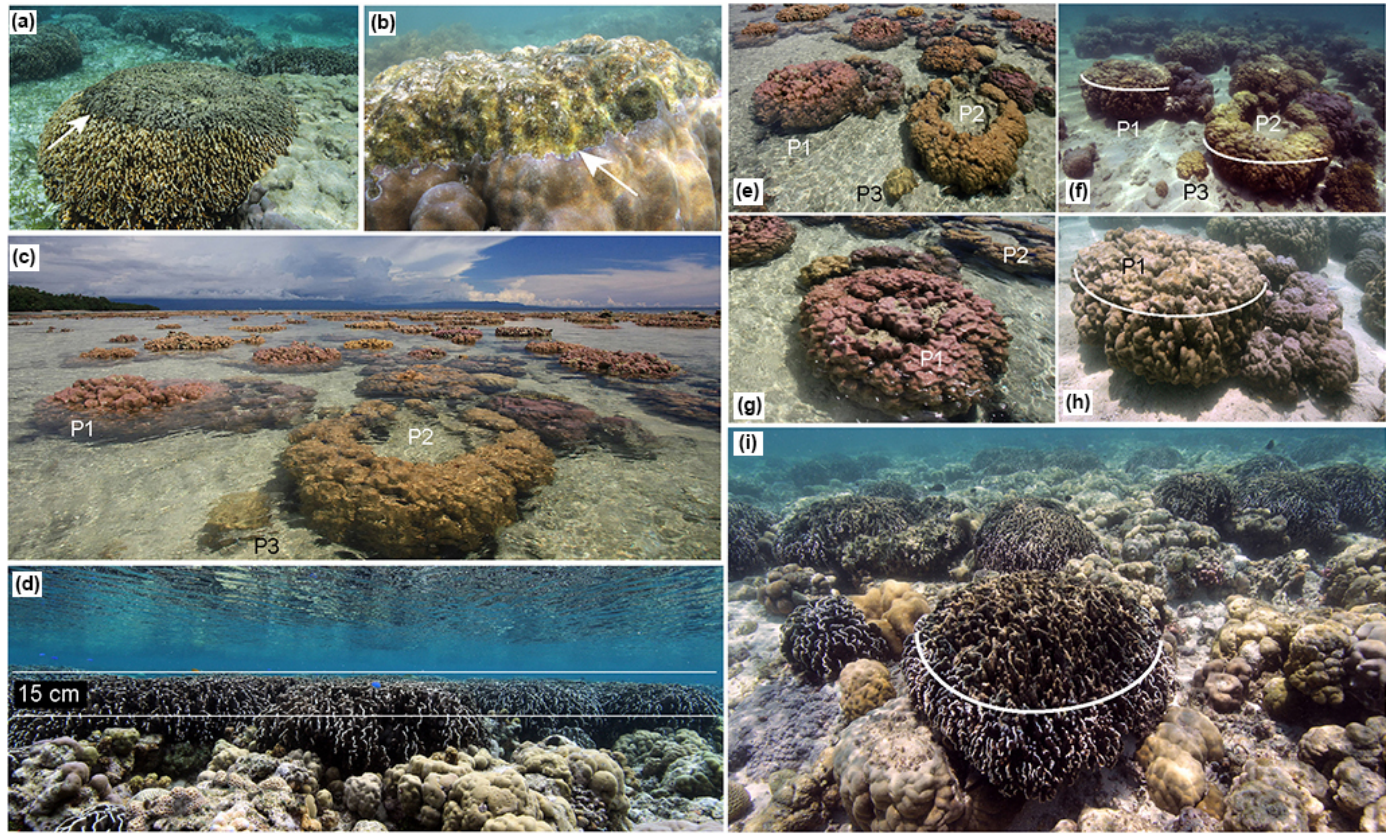

Figure 1. Bunaken reef flats. (a) Close-up of one Heliopora coerula colony with clear tissue mortality on the upper part of the colonies; (b) same for a Porites lutea colony; (c) reef flat Porites colonies observed at low spring tide in May 2014. Even partially above water a few hours per month in similar conditions, the entire colonies were alive. (d) A living Heliopora coerula (blue coral) community in 2015 in a keep-up position relative to mean low sea level, with almost all the space occupied by corals. In that case, a $15 \mathrm{~cm}$ sea level fall will impact most of the reef flat. (e-h) Before-after comparison of coral status for colonies visible in (c). In (e), healthy Porites lutea (yellow and pink massive corals) reef flat colonies in May 2014, observed at low spring tide. The upper part of colonies is above water, yet healthy; (f) same colonies in February 2016. The white lines visualize tissue mortality limit. Large Porites colonies (P1, P2) at low tide levels in 2014 are affected, while lower colonies (P3) are not. (g) P1 colony in 2014. (h) Viewed from another angle, the P1 colony in February 2016. (i) Reef flat community with scattered Heliopora colonies in February 2016, with tissue mortality and algal turf overgrowth.

WGS84 ellipsoid. Hence, raw Bitung SSH does not represent absolute depth above the Bitung seafloor. SLCH provides high quality data (available till early 2015) that have been controlled for most outliers and errors, and lower quality data that include the most recent coverage embodied in our period of interest (2015-2016). The Bitung tide-gauge stopped recording in many instances for reasons unknown to us, hence the records present many, irregularly spaced gaps.

In addition to the Bitung tide-gauge data, different sea level anomaly products were investigated, based on their temporal coverage and spatial resolution. First, we used gridded altimetry data in terms of Absolute Dynamic Topography (ADT), from the Archiving, Validation and Interpretation of Satellite Oceanographic Data (AVISO) center at the spatial resolution of $1 / 4^{\circ}$. ADT provides the sea level with respect to the geoid. Data are available from 1993 to 2016, allowing a long-term comparison of the sea level trends. The mean ADT over the period was extracted for a small area next to Bunaken Island $\left(1.5-1.7^{\circ} \mathrm{N} ; 124.5-124.8^{\circ} \mathrm{E}\right)$, a larger area ( 3 by 3 degrees around the smaller area) centered on Bunaken Island and including the north of Sulawesi and Tomini Bay in the south, and for Indonesia in its entirety. $\left(-14.9-10.0^{\circ} \mathrm{S}\right.$, $\left.94.9-140.0^{\circ} \mathrm{E}\right)$. The difference between the minimum value (observed in September 2015) and the 2005-2014 mean or the 1993-2016 mean periods were also computed. In addition, we also retrieved ADT data corresponding to the Bitung tide-gauge location to compare altimetry sea level anomalies with in situ data. The selected retrieved location is the closest available from Bitung $\left(1.375^{\circ} \mathrm{N}\right.$ and longitude $\left.125.125^{\circ} \mathrm{E}\right)$. To compute sea level anomalies, we considered only the periods of time covered by both data sets in order to use a common baseline.

Second, to extract geophysical information from higher spatial resolution altimeter data, we used the alongtrack measurements from SARAL/AltiKa Geophysical Data Records (GDRs) that were distributed by the AVISO service (http://www.aviso.altimetry.fr/fr/). This data set was chosen because the new Ka-band instrument from SARAL has a finer spatial resolution and enables a better observation of coastal zones (Verron et al., 2015). Data extend from March 2013 (cycle 1 of the satellite mission) to May 2016 (cycle 33), with a repeat period of 35 days. Over this period, we use all altimeter observations located between $10^{\circ} \mathrm{S}-$ $10^{\circ} \mathrm{N}$ and $105-140^{\circ}$ E. Two tracks (No.535 and No.578) intersect the north of Sulawesi and contain sampling points just off Bunaken Island. The data analysis is done in terms 
of sea level anomalies (SLA) computed from the $1 \mathrm{~Hz}$ altimeter measurements and geophysical corrections provided in GDRs products. The SLA data processing and editing are described in details in Birol and Niño (2015). The $1 \mathrm{~Hz}$ SLA data have a spatial resolution of $\sim 7 \mathrm{~km}$ along the satellite tracks. In order to quantify the spatial variations of the regional sea level change in March 2013-May 2016, a linear trend model is applied (using a simple linear regression) to the individual SLA time series observed at the different points along the altimeter tracks that cross the area of interest. The trend is the slope of the regression (in $\mathrm{cm} \mathrm{year}^{-1}$ ). The resulting 3-year sea level trend values can be represented on a map.

\section{Results}

\subsection{Mortality rates per dominant coral genus}

For all colonies found on the six stations, dead tissues were found on the top and upper-flank of the colonies, with the lower part of the colonies remaining healthy (Fig. 1). Mortality was not limited to microatoll-shaped colonies only. Round massive colonies were also impacted. On microatolls and other colonies that may have lived close to MLW, the width of dead tissue appeared to be around a maximum of $15 \mathrm{~cm}$. Dead tissues were systematically covered by turf algae, with cyanobacteria in some cases, suggesting that the stressor responsible for the mortality occurred a few months earlier. There were no obvious preferential directions in tissue damage at the colony surface, as previously reported for intertidal reef flat corals in Thailand (Brown et al., 1994).

The six surveyed reef flat locations were dominated by $H$. coerulea and $P$. lutea, while other genus and species occurred less frequently (Table 1). When taking into account all genus, up to $85 \%$ of the colonies were dead (Site 5). The average mortality was around $58 \%$ with all sites included (Fig. 2). When it was present, Goniastrea minuta colonies were the most impacted, with a $82 \%$ mortality on average (Fig. 2). Highest mortalities were found on keep-up communities relative to sea level (Fig. 1).

\subsection{Map of occurrences of mortality}

The survey around the island revealed presence of mortality all around the island except the north reef flats, where corals were scarce and encrusting (Fig. 2). The same coral genus as listed in table 1 were impacted, but mortality levels differed depending on colony heights. When colonies were clearly below the present minimum sea level, they remained healthy (Fig. 1). Locations of positive observations show that mortality has occurred mostly along the crest, which is expected to be the most vulnerable during sea level fall (Fig. 2). The spatial envelop of mortality occurrences is shown on the Bunaken map in Fig. 2. The survey and generalization using the habitat map suggests that nearly $163 \mathrm{ha}$, or $30 \%$ of
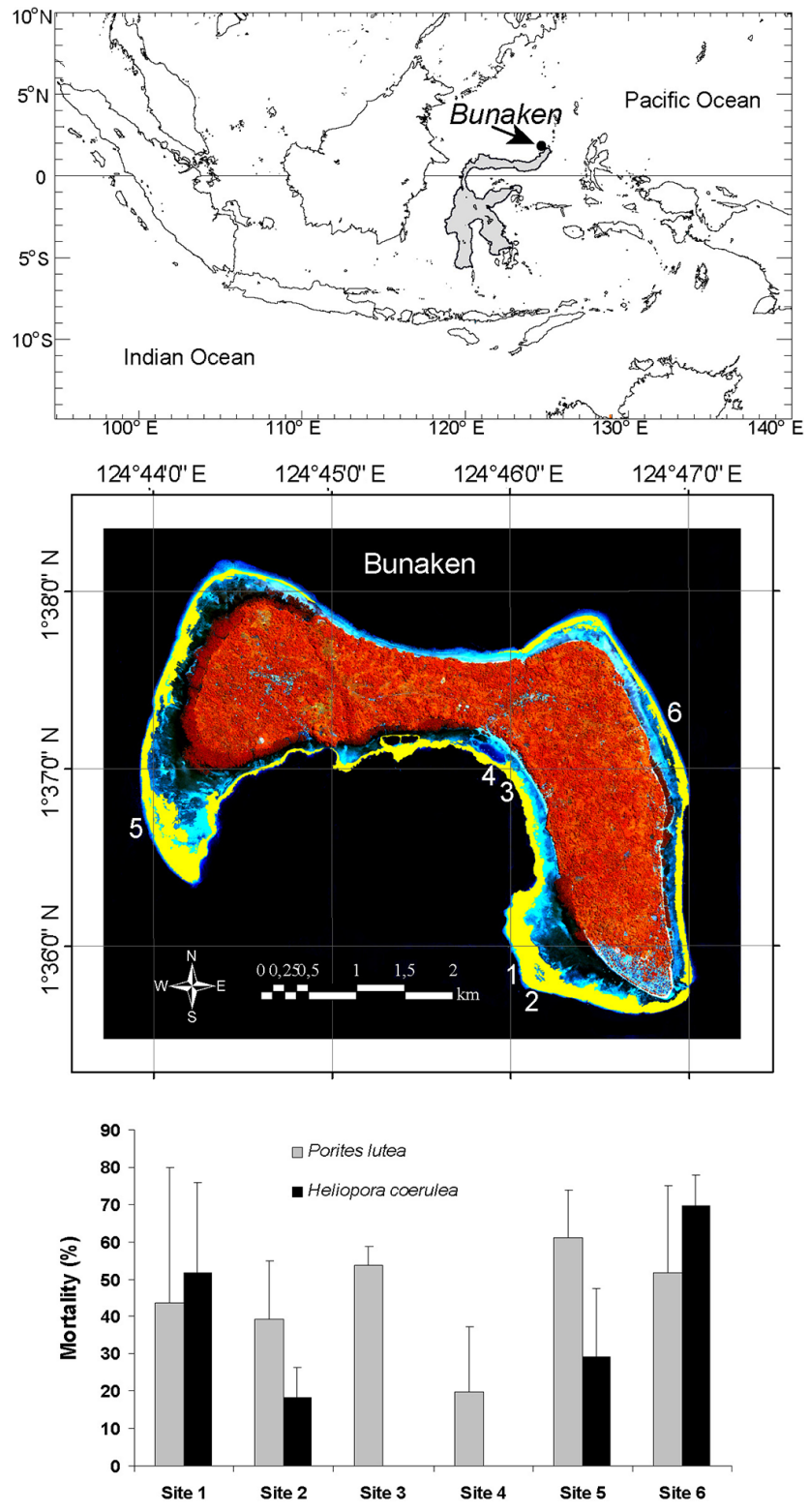

Figure 2. Top: Bunaken location in the north of Sulawesi, the large island in grey. Middle: Close-up of the island of Bunaken. The yellow area shows where coral mortality occurred around Bunaken reef flats, with the position of six sampling stations. Dark areas between the yellow mask and the land are seagrass beds. Blue-cyan areas are slopes and reef flats without mortality. Bottom: Mortality rates for the six sites for two dominant species Porites lutea and Heliopora coerulea. The latter is not found on Sites 3 and 4 . The number of colonies ranged between 10 and 30 per transect, depending on the size of the colonies. 
Table 1. Mortality rates (mean \pm standard deviation, $n=6$ ) of all corals for the six reef flat sites. The three dominant species were Porites lutea, Heliopora coerulea, and Goniastrea minuta. Several species and genus were found only once. Standard deviation is not shown when only one measurement per type of coral could be achieved (i.e., one colony per site).

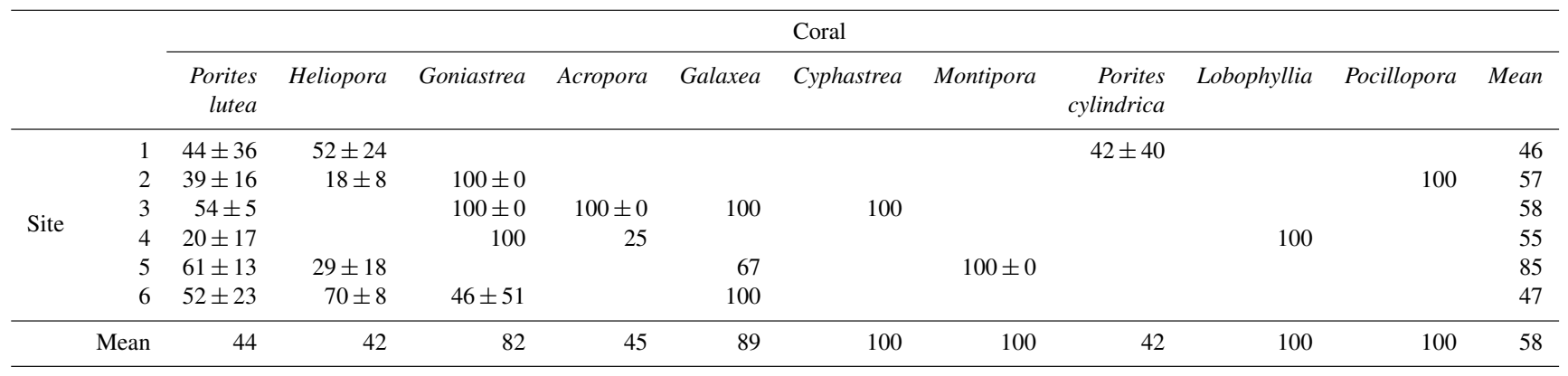

the entire reef system, has been impacted by some mortality. However, this does not mean that $30 \%$ of the reef has died.

\subsection{Comparison between tide-gauge and altimetry data}

We found a good correlation (Pearson $r=0.83$ ) between sea level anomalies from altimetry (ADT) and from tidegauge. The two time series are compared in Fig. 3 to confirm the agreement. The Bitung sea-level data reveal the type of sea-level variations that likely occurred around Bunaken, although patterns may not be exactly the same considering the distances between sites. Figure 3 shows the daily mean sea level from the available Bitung data (that can be compared to sea level as provided by altimetry), and the daily lowest level (which can not be directly measured by altimetry). This graph suggests what the range of sea level variations happening in Bunaken before El Niño likely was, due to normal tide fluctuations. The daily lowest value (blue curve in middle and lower panels in Fig. 3) exhibited a $\sim 40 \mathrm{~cm}$ variation from neap tide to spring tide. In 2014, and 2015, we witnessed Porites corals that had the upper part of the colonies well above the sea level, and without signs of mortality during spring tide conditions (Fig. 1). Hence, the upper limit of coral survival is somewhere around $20 \mathrm{~cm}$ above the spring tide, the lowest level for the end of the period shown in Fig. 3. In other words, the limit of coral survival is close to the mean of the daily lowest level curve. If this mean value changes through time, the limit of mortality also changes dynamically. The $\sim 15 \mathrm{~cm}$ fall that we observed on altimetry data around Bunaken and on most of eastern Indonesia changed the values of the lowest levels for a short time (several weeks), but these changes lasted long enough so that coral tissues were damaged by excessive UV and air exposure. During a few weeks in August-September 2015, this fall resulted in a shift of the mean low level towards the pre-El Niño lowest levels shown in Fig. 3 (lower panel).
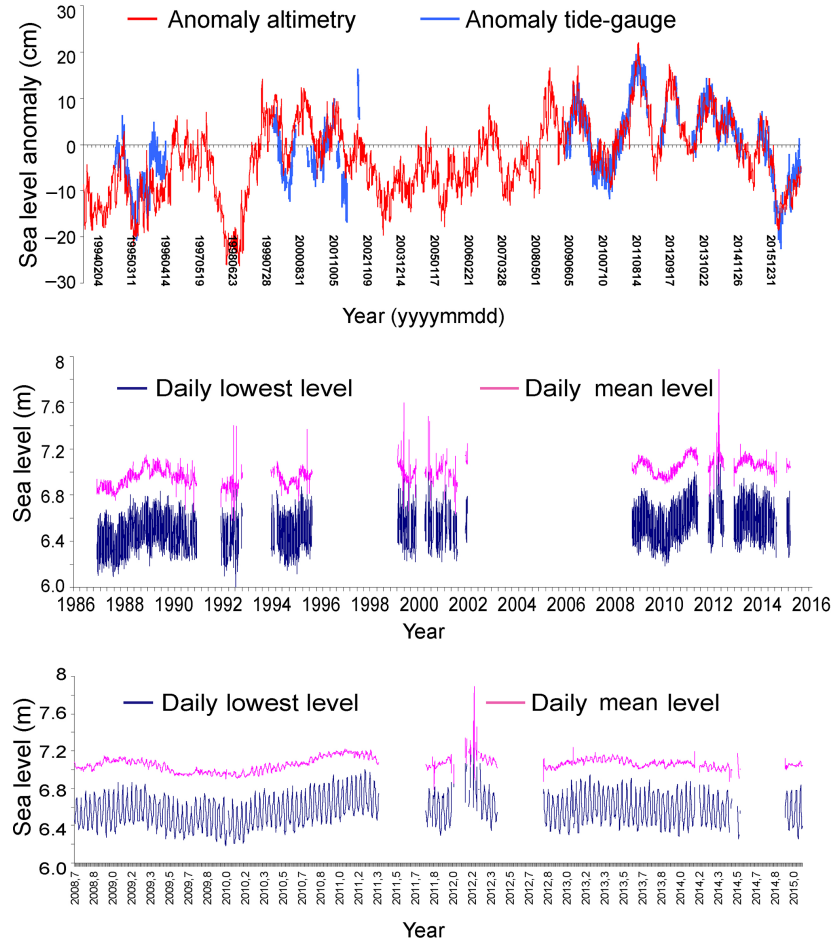

Figure 3. Sea-level data from the Bitung (east North Sulawesi) tide-gauge, referenced against Bako GPS station. On top, sea level anomalies measured by the Bitung tide-gauge station (low-quality data), and overlaid on altimetry ADT anomaly data for the 19932016 period. Note the gaps in the tide-gauge time series. Middle: Bitung tide-gauge sea level variations (high-quality data, shown here from 1986 till early 2015) with daily mean and daily lowest values. Bottom, a close-up for the 2008-2015 period.

\subsection{Absolute Dynamic Topography time series}

The ADT time series (Fig. 4) shows a significant sea level fall congruent with El Niño periods, at all spatial scales, although the pattern is not as pronounced at Indonesia-scale (Fig. 4). The 1997-1998 and the 2015-2016 years display the highest falls. The September 2015 value is the local minima, consid- 

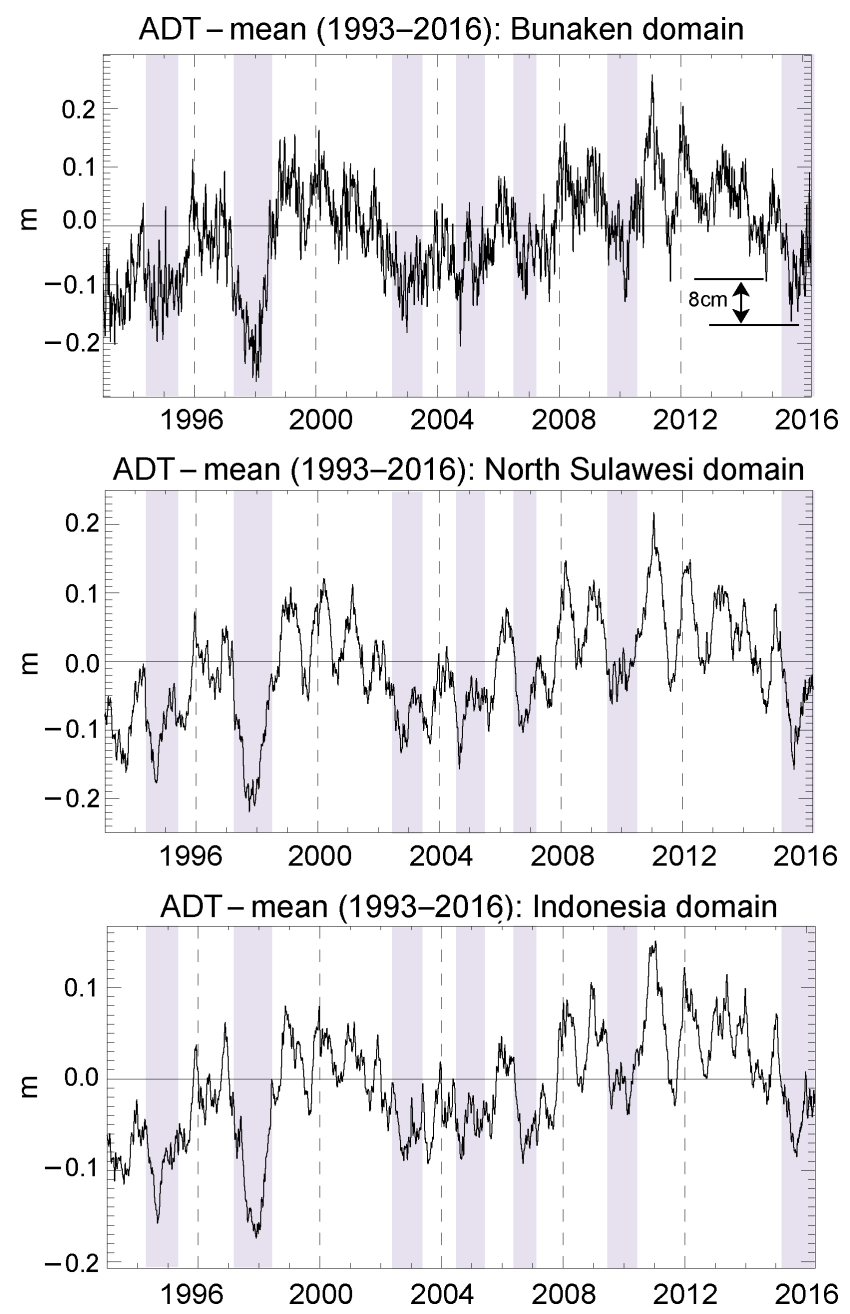

Figure 4. Time series of ADT, minus the mean over the 1993-2016 period, for Bunaken Island (top), North Sulawesi (middle), and Indonesia (bottom). The corresponding spatial domains are shown in Fig. 6. El Niño periods (http://www.cpc.ncep.noaa.gov/products/ analysis_monitoring/ensostuff/ensoyears.shtml) are depicted with grey shadings. The September 2015 minimum corresponds to an $8 \mathrm{~cm}$ fall compared to the minima then four previous years, and a $14 \mathrm{~cm}$ fall compared to the 1993-2016 mean. The 1998 El Niño displays the largest sea level fall.

ering the last 10 years (Fig. 4). The $8 \mathrm{~cm}$ fall in September 2015 compared to the previous 4 years, and the $15 \mathrm{~cm}$ fall compared to the 1993-2016 mean (Fig. 4) is consistent with the pattern of mortality following a maximum of $\sim 15 \mathrm{~cm}$ width on the top of the impacted micro-atolls and colonies that were living close to the mean low sea level before the event (Fig. 1).

\subsection{Sea level anomaly trends}

SARAL/AltiKa data in March 2013-May 2016 are shown in Fig. 5 for a small area that includes Bunaken Island (at the top) and a larger box (at the bottom) covering part of
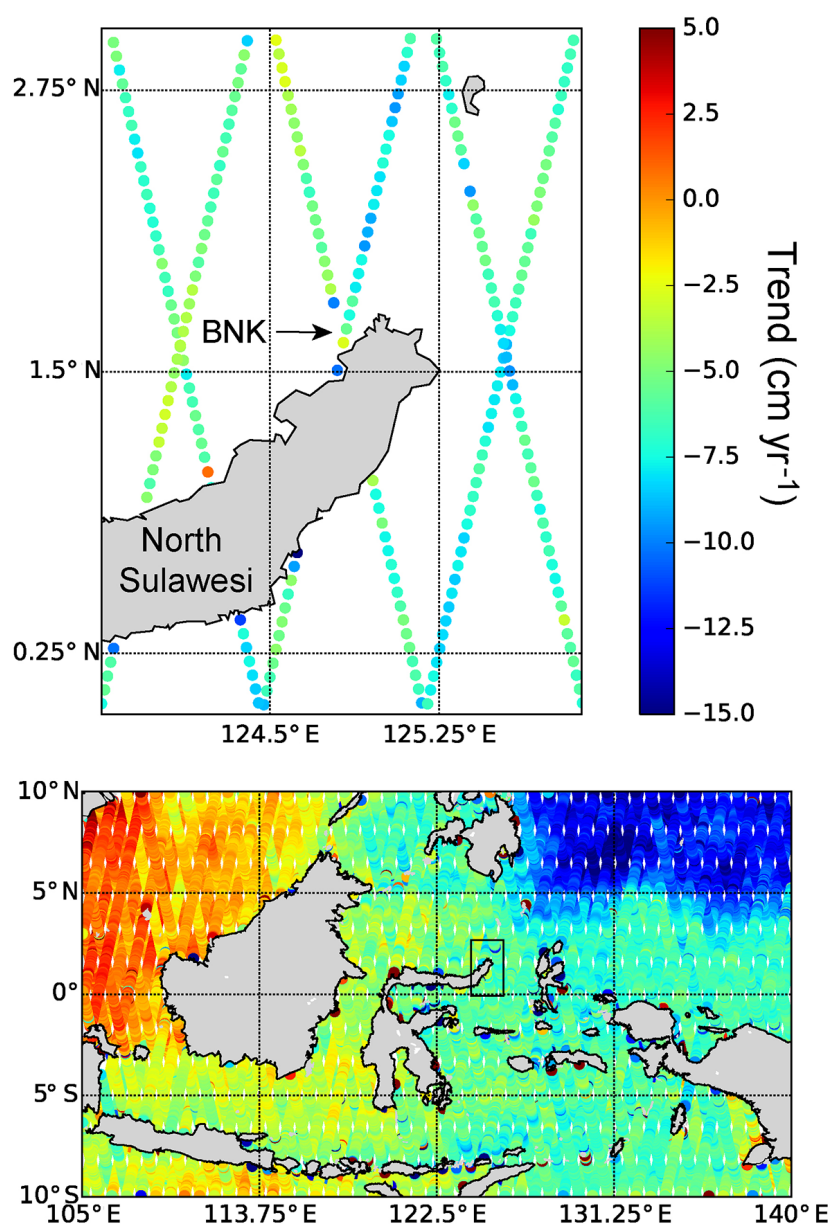

Figure 5. Top: Map of along-track SLA trend (in $\mathrm{cm} y e a r^{-1}$ ), 2013-2016, for the north Sulawesi area. The position of Bunaken Island is shown (BNK). Bottom: Map of along-track SLA trend (1 Hz), 2013-2016, for Indonesia. The domain on the top panel is the rectangle in the Indonesia map of the bottom panel.

the western equatorial Pacific Ocean and Coral Triangle. A substantial sea level fall is observed around Bunaken Island, with values ranging from 4 to $8 \mathrm{~cm}_{\text {year }}{ }^{-1}$ (12 to $24 \mathrm{~cm}$ accumulated over 3 years, Fig. 5). Further analysis of the individual sea level time series indicates that the overall trend is explained, and accelerated, by the fall due to El Niño (not shown). This result agrees with findings from Luu et al. (2015) around Malaysia and can be extended to much of the Coral Triangle. Fig. 5 shows that this phenomenon is consistent over a large part of Indonesia and the warm water pool, where strong differences in sea level variations (up to $-15 \mathrm{~cm}$ year $^{-1}$ ) are observed between Asia and Micronesia, north of $5^{\circ} \mathrm{N}$ and east of $130^{\circ} \mathrm{E}$.

\section{Discussion}

A common ground exists between this study and the use of massive corals to reconstruct sea level. Reconstructions of 
paleo-sea levels, whether it is induced by tectonic events or not, is a science that takes advantage of the shape of modern or fossil micro-atolls (Meltzner et al., 2006). However, we stress to the reader that this study is not about reconstructing sea levels using dead corals. Rather, we explained coral mortality using sea level data, primarily from altimetry data. The agreement between altimetry and tide-gauge data (Fig. 3) confirms that altimetry data are suitable to monitor sea level variation close to a coast. More specifically, this confirms the value of using altimetry observations to help identifying the cause of shallow coral mortality, even without any other local in situ source of sea level data, as in Bunaken.

Interestingly, we found that sea level fall appeared to be responsible for coral mortality, while most recent climate change literature is generally focused on the present and future effects of sea level rise (Hopley, 2011). Geological records and present-time observation have already demonstrated that sea level variation is a driver of coral community changes. Sea level rise can have antagonistic effects: on the one hand, it can provide new growing space for corals. On the other hand, higher depth may enhance wave propagation and increase physical breakage in areas that were previously sheltered. If sea level rise is fast, corals may not keep-up and the reef may drown relative to the new sea level. As such, sea level rise is seen as one of the three main climate change threats for coral reefs. This study reminds the reader that the processes can be much more variable at ecological time scales.

We aimed to document the spatial scale and the cause of an ecological event that could be easily overlooked when documenting the 2016 El Niño impact on Indonesian coral reefs. Many studies have emphasized the role of hydrodynamics and sea level on the status and mortality of coral communities growing on reef flats (e.g., Anthony and Kerswell, 2007; Hopley, 2011; Lowe et al., 2016). Here we emphasize, with altimetry data, used for one of the first times for a reef flat study (Tartinville and Rancher, 2000), that the 2015-2016 El Niño has generated such mortality, well before any ocean warming-induced bleaching. The exact time of the mortality remains unknown, but it is likely congruent to the lowest level in September 2015. The aspect of the colonies in February 2016, with algal turf covering the dead part (Fig. 1), is also consistent with a lowest sea level occurring a few months earlier. Fig. 1 shows corals that were fine in May 2015 even when exposed to aerial exposure during low spring tide, without wave or wind, for several hours, during several days of spring tide. Thus, we assume the mortality was due to several weeks of lower water, including spring tide periods, which are compatible with the temporal resolution of the altimetry observations. The aerial exposure could have led to tissue heating, desiccation, photosystem or other cell function damage (Brown, 1997). It is possible that colonies could have looked bleached during that period (Brown et al., 1994). Lack of wind-induced waves in the September period also prevented wave washing and water mixing which could have limited the damage (Anthony and Kerswell, 2007).

The various satellite Sea Surface Temperature (SST) products for coral bleaching warning, available at http:// coralreefwatch.noaa.gov/, do not suggest any bleaching risk in the Bunaken region before June 2016, hence the wide mortality we observed can not be simply explained by ocean warming due to El Niño. We also verified on http: //earthquake.usgs.gov/ that between the May 2015 habitat mapping survey and the February 2016 coral survey, no tectonic movement could generate such a $15 \mathrm{~cm}$-uplift, with an upward shift of coral colonies relative to sea level, as it has been reported in different places in the past, including in Sumatra, Indonesia after the 2004 Sumatra Earthquake (Meltzner et al., 2006). An uplift of that magnitude would be related to a significant event, but there are no reports higher than a 6.3 magnitude earthquake (16 September 2015, origin $1.884^{\circ} \mathrm{N} 126.429^{\circ} \mathrm{E}$ ) in the north Sulawesi area for that period.

Altimetry data have been seldom used to study coral reef processes, even in a sea level rise era that may affect coral reef communities and islands. They have been useful to assess the physical environment (wave, tide, circulation, lagoon water renewal) around islands and reefs (e.g., Tartinville and Rancher, 2000; Andréfouët et al., 2001, 2012; Burrage et al., 2003; Gallop et al., 2014), or explain larval connectivity and offshore physical transport between reefs (e.g., Christie et al., 2010), but this is the first time to our knowledge that altimetry data, including the new SARAL/AltiKa data, are related to a coral ecology event. Different measures of sea level and sea level anomalies confirmed an anomalous situation following the development of the 2015-2016 El Niño, resulting in lower sea level regionally averaging $8 \mathrm{~cm}$ in the north of Sulawesi compared to the previous 4 years (Fig. 3-6). Mortality patterns on coral colonies strongly suggest that sea level fall is responsible for the coral die-off that could reach $80 \%$ of reef flat colonies that were in a keep-up position relative to, usually, rising sea levels in this region (Fenoglio-Marc et al., 2012).

While mortality due to sea level fall was characterized opportunistically in Bunaken NP, the impact remains unquantified elsewhere. However, we speculate that similar events have occurred throughout the Indonesian seas when considering ADT values for this region (Fig. 6). The stretch of reefs and islands between South Sumatra, the south of Java, the Flores Sea and Timor; and the domain centered by the island of Seram and comprised of east Sulawesi, West Papua and the Banda Sea could have been particularly impacted by sea level fall. These areas have substantial reef flat presence (e.g., for the Lesser Sunda region comprised between Bali, Maluku and Timor islands, see maps in Torres-Pulliza et al., 2013).

Specifically for Bunaken NP, the event we have witnessed helps to explain long-term observations of reef flat dynamics and resilience. Indeed, our surveys along with historical 

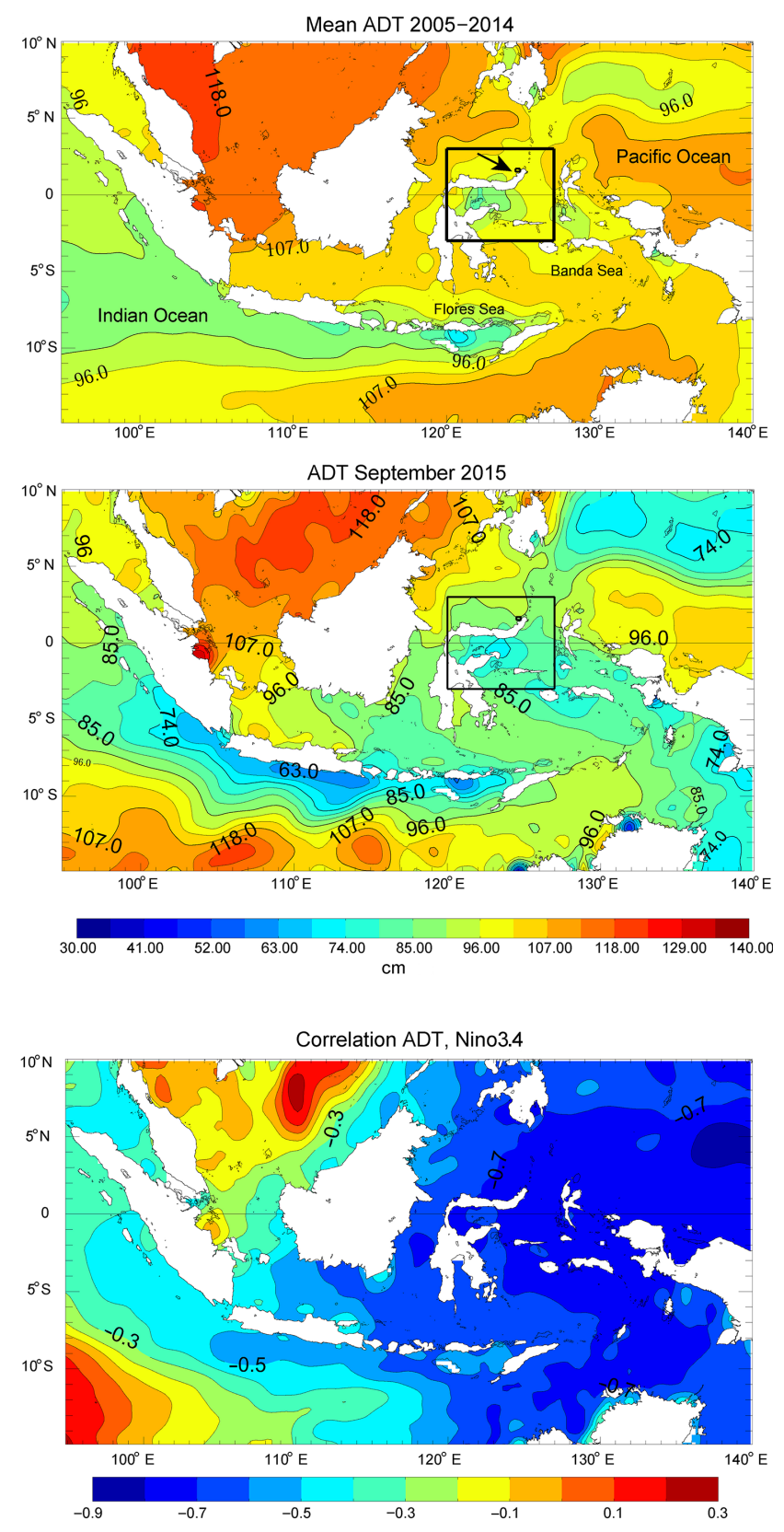

Figure 6. Top: Map of the 2005-2014 Absolute Dynamic Topography (ADT, in centimeters) average over Indonesia. Middle: Map of the September 2015 ADT mean value over Indonesia. The two squares indicate the domain just around Bunaken Island (arrow on top panel) and the north Sulawesi domain used for the ADT time series presented in Fig. 4. Bottom: Map of correlation between ADT and the Nino3.4 index (1993-2016, monthly average minus seasonal cycle).

and very high-resolution satellite imagery show the fast colonization of reef flats by Heliopora coerula and by carpets of branching Montipora around Bunaken Island in the years 2004-2012, a period congruent to substantial rising sea levels (Fig. 3) (Fenoglio-Marc et al., 2012). Rising seas have allowed these corals, especially fast growing and opportunistic ones like H. coerula (Babcock, 1990; Yasuda et al., 2012) to cover previously bare reef flats by taking advantage of the additional accommodation space. A similar process occurred in the Heron Island reef flats in Australia, with an artificially induced sea level rise due to local engineering work (Scopélitis et al., 2011). In Bunaken, and probably elsewhere in Indonesia and the Coral Triangle, the 2015-2016 El Niño event counter-balances this period of coral growth with rising seas.

The ADT time series (Fig. 4) suggests that similar low level situations have probably previously occurred, and almost certainly at least in 1997-1998, the highest anomaly on altimetry record. Reef flat coral mortality reported in the Coral Triangle as the consequences of bleaching in these years is thus most likely also the consequences of sea level fall. The discrimination between thermal and sea level fallinduced mortality could be difficult to pinpoint on reef flats if surveys occurred several months after the thermally-induced bleaching. In Bunaken NP, mortality due to sea level fall preceded the first occurrences of bleaching in Indonesia by nearly 7 months, as reported in April 2016. The real impact of sea level fall could have been largely underestimated during all El Niño episodes and especially in Asia. The implications for coral reef monitoring in the Coral Triangle are substantial. Surveys that may have started in April 2016 may have been confused and assigned reef flat mortalities to coral bleaching. In future years, monitoring SLA may be as important as monitoring SST. While there are several SST-indices specifically used as early warning signals for potential coral bleaching (Teneva et al., 2012), there are no sea level indices specific for coral reef flats. However, several ENSO indices can help tracking the likelihood of similar events for Indonesia. The high correlation between the NINO3.4 index and ADT over the 1993-2016 period (monthly mean minus seasonal baseline, Fig. 6) shows this potential. Other indices, such as the Southern Oscillation Index (SOI, computed as the pressure difference between Darwin and Tahiti), or the equatorial SOI (defined by the pressure difference between the Indonesia-SLP, standardized anomalies of sea level, and the equatorial Eastern Pacific SLP) appear to be even more suitable over Indonesia and the Coral Triangle to develop suitable early warning signals related to sea level variations.

\section{Conclusions}

This study reports coral mortality in Indonesia after an El Niño-induced sea level fall. The fact that sea level fall, or extremely low tides, induces coral mortality is not new, but this study demonstrates that through rapid sea level fall, the 2015-2016 El Niño has impacted Indonesian shallow coral reefs well before high sea surface temperature could trigger any coral bleaching. Sea level fall appears as a major mortality factor for Bunaken Island in North Sulawesi, and altimetry suggests similar impact throughout Indonesia. Our 
findings confirm that El Niño impacts are multiple and the different processes need to be understood for an accurate diagnostic of the vulnerability of Indonesian coral reefs to climate disturbances. This study also illustrates how to monitor local sea level to interpret changes in a particular coastal location. For Indonesia coral reefs, in addition to sea level fall, depending on the ENSO situation further changes can be expected due to coral bleaching, diseases, predator outbreaks, storms and sea level rise (Baird et al., 2013; Johan et al., 2014). Considering the amount of services that shallow coral reefs offer, in coastal protection, food security and tourism, the tools presented here offer valuable information to infer the proper diagnostic after climate-induced disturbances.

\section{Data availability}

Altimetry and tide-gauge data are publicly available from http://www.aviso.altimetry.fr/en/data.html and http://uhslc.soest.hawaii.edu/thredds/uhslc_quality_daily. html?dataset=RQD033A (Caldwell et al., 2015). The authors are not supposed to redistribute these data. Biological data (coral mortality) are provided in the paper (Table 1 and Fig. 2).

Competing interests. The authors declare that they have no conflict of interest.

Acknowledgements. This study was possible with the support of the Infrastructure Development of Space Oceanography (INDESO) project in Indonesia, and its Coral Reef Monitoring Application. Fieldwork on Bunaken Island was authorized by the research permit 4B/TKPIPA/E5/Dit.KI/IV/2016 delivered by the Ministry of Research, Technology and Higher Education of the Republic of Indonesia to SA. This is ENTROPIE contribution 178.

Edited by: G. Herndl

Reviewed by: two anonymous referees

\section{References}

Ampou, E. E.: Caractérisation de la résilience des communautés benthiques récifales par analyse d'images à très haute résolution multi-sources: le cas du Parc National de Bunaken, Indonésie, PhD Dissertation; Université Paul Sabatier Toulouse, France, 2016.

Andréfouët, S., Pages, J., and Tartinville, B.: Water renewal time for classification of atoll lagoons in the Tuamotu Archipelago (French Polynesia), Coral Reefs, 20, 399-408, 2001.

Andréfouët, S., Ardhuin, F., Queffeulou, P., and Le Gendre, R.: Island shadow effects and the wave climate of the Western Tuamotu Archipelago (French Polynesia) inferred from altimetry and numerical model data, Mar. Poll. Bull., 65, 415-424, 2012.
Anthony, K. R. N. and Kerswell, A. P.: Coral mortality following extreme low tides and high solar radiation, Mar. Biol., 151, 16231631, 2007.

Babcock, R.: Reproduction and development of the blue coral $\mathrm{He}$ liopora coerulea (Alcyonaria: Coenothecalia), Mar. Biol., 104, 475-481, 1990.

Baird, A. H., Pratchett, M. S., Hoey, A. S., Herdiana, Y., and Campbell, S. J.: Acanthaster planci is a major cause of coral mortality in Indonesia, Coral Reefs, 32, 803-812, 2013.

Baker, A. C., Glynn, P. W., and Riegl, B.: Climate change and coral reef bleaching: An ecological assessment of long-term impacts, recovery trends and future outlook, Estuar. Coast. Shelf S., 80, 435-471, 2008.

Birol, F. and Niño, F.: Ku- and Ka-band Altimeter Data in the Northwestern Mediterranean Sea: Impact on the Observation of the Coastal Ocean Variability, Mar. Geod., 38, 313-327, doi:10.1080/01490419.2015.1034814, 2015.

Brown, B. E.: Adaptations of reef corals to physical environmental stress, Adv. Mar. Biol., 31, 221-299, 1997.

Brown, B. E., Dunne, R. P., Scoffin, T. P., and LeTessier, M. D. A.: Solar damage in intertidal corals, Mar. Ecol. Prog. Ser., 105, 219-230, 1994.

Burrage, D. M., Steinberg, C. R., Mason, L. B., and Bode, L.: Tidal corrections for TOPEX altimetry in the Coral Sea and Great Barrier Reef Lagoon: Comparisons with longterm tide gauge records, J. Geophys. Res., 108, 3241, doi:10.1029/2000JC000441, 2003.

Caldwell, P. C., Merrfield, M. A., and Thompson, P. R.: Sea level measured by tide gauges from global oceans - the Joint Archive for Sea Level holdings (NCEI Accession 0019568), Version 5.5, NOAA National Centers for Environmental Information, Dataset, doi:10.7289/V5V40S7W, 2015.

Christie, M. R., Tissot, B. N., Albins, M. A., Beets, J. P., Jia, Y., Ortiz, D. M., Thompson, S. E., and Hixon, M. A.: Larval Connectivity in an Effective Network of Marine Protected Areas, PlosOne, 5, e15715, doi:10.1371/journal.pone.0015715, 2010.

English, S., Wilkinson, C., and Baker, V.: Survey Manual for Tropical Marine Resources, 2nd edition, ASEAN. ed. Australia Marine Science Project, Living Coastal Resources, Australian Institute of Marine Science, Townsville, Australia, 1997.

Fenoglio-Marc, L., Schone, T., Illigner, J., Becker, M., Manurung, P., and Khafid: Sea level change and vertical motion from satellite altimetry, tide gauges and GPS in the Indonesian region, Mar. Geod., 35, 137-150, 2012.

Gallop, S. L., Young, I. R., Ranasinghe, R., Durrant, T. H., and Haigh, I. D.: The large-scale influence of the Great Barrier Reef matrix on wave attenuation, Coral Reefs, 33, 1167-1178, 2014.

Glynn, P. W.: El Nino-Southern Oscillation mass mortalities of reef corals; a model of high temperature marine extinctions?, Geol. Soc. Spec. Publ., 178, 117-133, 2000.

Goodwin, I. and Harvey, N.: Subtropical sea-level history from coral microatolls in the Southern Cook Islands, since 300 AD, Mar. Geol., 253, 14-25, 2008.

Guest, J. R., Baird, A. H., Maynard, J. A., Muttaqin, E., Edwards, A. J., Campbell, S. J., Yewdall, K., Affendi, Y. A., and Chou, L. M.: Contrasting patterns of coral bleaching susceptibility in 2010 suggest an adaptive response to thermal stress, PlosOne, 7, e33353, doi:10.1371/journal.pone.0033353, 2012. 
Hoegh-Guldberg, O.: Climate change, coral bleaching and the future of the world's coral reefs, Mar. Freshwater Res., 50, 839866, 1999.

Hoeksema, B.: Delineation of the Indo-Malayan centre of maximum marine biodiversity: The Coral Triangle, in: Biogeography, Time, and Place: Distributions, Barriers, and Islands, edited by: Renema, W., Springer, 117-178, 2007.

Hopley, D.: Climate change: impact of sea level rise on reef flat zonation and productivity, in: Encyclopedia of modern coral reefs. Structure, form and process, edited by: Hopley, D., Springer, Berlin, 2011.

Johan, O., Bengen, D. G., Zamani, N. P., Suharsono, Smith, D., Lusiastuti, A. M., and Sweet, M. J.: Microbial community of black band disease on infection, healthy, and dead part of scleractinian Montipora sp. colony at Seribu Islands, Indonesia, Indonesian Aquaculture Journal, 9, 1-11, 2014.

Lowe, R., Pivan, X., Falter, J., Symonds, G., and Gruber, R.: Rising sea levels will reduce extreme temperature variations in tide-dominated reef habitats, Science Advances, 2, e1600825, doi:10.1126/sciadv.1600825, 2016.

Luu, Q. H., Tkalich, P., and Tay, T. W.: Sea level trend and variability around Peninsular Malaysia, Ocean Sci., 11, 617-628, doi:10.5194/os-11-617-2015, 2015.

McPhaden, M. J.: El Niño and La Niña: Physical Mechanisms and Climate Impacts, in: The Impact of Environmental Variability on Ecological Systems, edited by Vasseur, D. A. and McCann, K. S., Springer, New York, 1-16, 2007.

Meltzner, A. J., Sieh, K., Abrams, M., Agnew, D. C., Hudnut, K. W., Avouac, J. P., and Natawidjaja, D. H.: Uplift and subsidence associated with the great Aceh-Andaman earthquake of 2004, J. Geophys. Res.-Sol. Ea., 111, B02407, doi:10.1029/2005JB003891, 2006.

Neumann, A. C. and Macintyre, I. G.: Reef response to sea level rise: keep-up, catch-up or give-up?, Proc. of the 5th Int. Coral Reef Congress, Tahiti, 3-105-110, 1985.

Ray, R., Egbert, G., and Erofeeva, S.: A brief overview of tides in the Indonesian Seas, Oceanography, 18, 74-79, 2005.
Schiermeier, Q.: Hunting the Godzilla El Niño, Nature, 526, 490491, 2015.

Scopélitis, J., Andréfouët, S., Phinn, S., Done, T., and Chabanet, P.: Coral colonisation of a shallow reef flat in response to rising sea level: quantification from 35 years of remote sensing data at Heron Island, Australia, Coral Reefs, 30, 951-965, 2011.

Smithers, S. G. and Woodroffe, C. D.: Microatolls as sea-level indicators on a mid-ocean atoll, Mar. Geol., 168, 61-78, 2000.

Suharsono: Ecological and physiological implications of coral bleaching at Pari Island, Thousand Islands, Indonesia (Electronic Thesis or Dissertation), University of Newcastle Upon Tyne, 1990.

Tartinville, B. and Rancher, J.: Wave-induced flow over Mururoa atoll reef, J. Coastal Res., 16, 776-781, 2000.

Teneva, L., Karnauskas, M., Logan, C., Bianucci, L., Currie, J., and Kleypas, J.: Predicting coral bleaching hotspots: The role of regional variability in thermal stress and potential adaptation rates, Coral Reefs, 31, 1-12, 2012.

Torres-Pulliza, D., Wilson, J., Darmawan, A., Campbell, S., and Andréfouët, S.: Ecoregional scale seagrass mapping: A tool to support resilient MPA network design in the Coral Triangle, Ocean Coastal Management, 80, 55-64, 2013.

Verron, J., Sengenes, P., Lambin, J., Noubel, J., Steunou, N., Guillot, A., Picot, N., Coutin-Faye, S., Sharma, R., Gairola, R. M., Raghava Murthy, D. V. A., Richman, J. G., Griffin, D., Pascual, A., Rémy, F., and Gupta, P. K.: The SARAL/AltiKa Altimetry Satellite Mission, Mar. Geod., 38, 2-21, 2015.

Wouthuyzen, S., Abrar, M., and Lorwens, J.: Pengungkapan Kejadian Pemutihan Karang Tahun 2010 di Perairan Indonesia Melalui Analisis Suhu Permukaan Laut, Oseanologi Dan Limnol. Indones., 1, 305-327, 2015.

Yasuda, N., Abe, M., Takino, T., Kimura, M., Lian, C., Nagai, S., Nakano, Y., and Nadaoka, K.: Large-scale mono-clonal structure in the north peripheral population of blue coral, Heliopora coerulea, Mar. Genomics, 7, 33-35, 2012. 